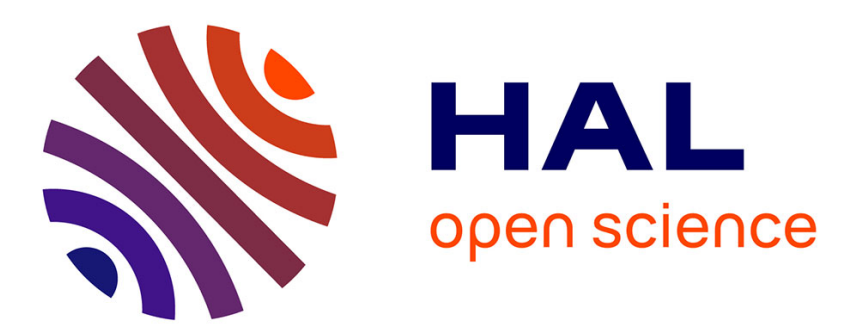

\title{
Family matters? Psychiatry, kinship and domestic responses to insanity in nineteenth-century England
}

Joseph Melling

\section{To cite this version:}

Joseph Melling. Family matters? Psychiatry, kinship and domestic responses to insanity in nineteenthcentury England. History of Psychiatry, 2007, 18 (2), pp.247-254. 10.1177/0957154X07076868 . hal00570889

\section{HAL Id: hal-00570889 \\ https://hal.science/hal-00570889}

Submitted on 1 Mar 2011

HAL is a multi-disciplinary open access archive for the deposit and dissemination of scientific research documents, whether they are published or not. The documents may come from teaching and research institutions in France or abroad, or from public or private research centers.
L'archive ouverte pluridisciplinaire HAL, est destinée au dépôt et à la diffusion de documents scientifiques de niveau recherche, publiés ou non, émanant des établissements d'enseignement et de recherche français ou étrangers, des laboratoires publics ou privés. 


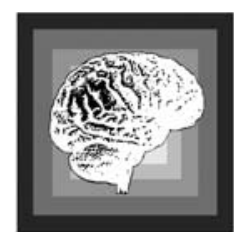

\title{
Family matters? Psychiatry, kinship and domestic responses to insanity in nineteenth-century England
}

\author{
JOSEPH MELLING* \\ University of Exeter
}

\begin{abstract}
Akihito Suzuki. Madness at Home. The Psychiatrist, the Patient and the Family in England, 1820-1860. Berkeley and Los Angeles: University of California Press, 2006. Pp. xi + 260. ISBN 0520245806.
\end{abstract}

\section{Family fortunes}

Studies of insanity in the nineteenth century have recently drawn social historians into a close reading of family ties. Using cultural and literary criticism as well as contemporary legal records, scholars have illuminated the intricate web of testimonies and transactions which made up the world of the mad. The themes of domestic discipline and disorder, contorted family wrangles, private intrigue and public scandal, familiar to readers of contemporary novelists, are vividly apparent in Akihito Suzuki's Madness at Home. This impressive study gives us an intelligent, richly textured and often brilliant portrait of almost two hundred individuals who became the subject of Commissions of Lunacy in the years 1823-61. In contrast to many cultural historians, Suzuki's scholarly narrative avoids the familiar dependence on formal literary texts as a guidebook to contemporary values. A wide variety of journalistic, periodical and legal materials are used to draw a compelling chronology of psychiatric practice and family relationships during a period when seminal legislation was introduced for the care of lunatics and the 'moral treatment' of the insane attracted wide support among the expanding profession of psychiatry.

Madness at Home is elegantly framed around individuals who became notable subjects of public view and often vigorous debate concerning the disposal of the property as well as the deposit of the wealthy lunatic in asylums during the four decades before 1860 . The author's graceful prose should not

* Address for correspondence: School of History and Centre for Medical History, University of Exeter, Exeter EX4 4RJ, UK. Email: J.L.Melling@ex.ac.uk 
disguise the boldness of the claims he makes in this book. For Suzuki argues that the family household and its domestic space was the most important and innovative site for the apprehension, detention and treatment of the lunatic in early Victorian England. The substance of familial interest in lunacy and its extraordinary influence can be traced to the importance of property relations as well as the moral authority claimed by families who faced the prospect of material loss as a result of the irrational behaviour of a family member (p. 75). While stressing the fundamental bonds of family property, Suzuki also emphasizes the mutual affection which tied individual personalities into the household's 'close-knit community' (p. 119).

In their pursuit of control over relatives, families not only resorted to the courts in extremis but also appealed to complex codes of conduct in civil society. The rules of proper decorum required respectable families to maintain a public façade of rank and status, disguising any coercive disciplines which they imposed on the personal delinquency of their members. The great expectations of fashionable society thereby caused considerable practical as well as moral strains when families struggled to contain the domestic disorders created by insanity. The pretence of domestic harmony was urgently required by a society which fostered the powerful myth of family love and the refuge of privacy within the filial home, reinforced by the pervasive belief in household obligations which distinguished these years as the 'golden age' of family life, revering kinship ties as the most important anchor of 'a society in turmoil and in danger of disintegration' (pp. 119, 121). This game of denial and deceit practised by notable families was cruelly exposed by the records of the Commission proceedings, often the last resort of desperate relatives, and these legal transactions form the staple source of this study.

These tensions prepared the ground for the growing popularity of the specialist lunatic asylum under the direction of trained psychiatrists, although Suzuki insists that such amenities merely gave solid form to the invisible wall of control which had previously fenced the lunatic within the family home (pp. 118, 137-8). In the growth of psychiatric practice, the formative moments of institutional medicine were defined by the tested experiences of the family household, rather than by the ideological underpinnings of civil society. This was most vividly exemplified in the development of moral treatment, transferring to the realm of institutions the lay insights and techniques devised in the homes of wealthy lunatics (pp. 116-17). In these and other respects the familial model provided the 'cultural relevancy' for psychiatric practices: far from the asylum subordinating families to the imperatives of enlightenment science and the calculus of capitalist accumulation, it is more appropriate to view the domestic realm of the household as colonizing the vision and management of the new asylums under the familial gaze of their superintendents.

The force of Suzuki's bold challenge to the older historiography of insanity echoes Roy Porter's (1987a) criticisms of the Foucauldian paradigm of 
institutional studies and the class analysis of Andrew Scull (1993). The careful documentation of the stresses placed on high-status families by the outbreak of insanity within the domestic household provides an important and neglected setting in which we can more clearly appreciate the appeal of the Victorian alienist and how the public ground was prepared for the creation of a central Lunacy Commission amid the politics of reform after 1832 (pp. 180-2). There is little doubt that the book makes a significant contribution to our understanding of early Victorian psychiatry and the wider institutional landscape in which insanity was identified and addressed in these decades. It is worth considering a little further the implications of Suzuki's arguments on current debates in the social and cultural history of insanity.

\section{Bringing it all back home: the family and the problem of insanity}

Suzuki's detailed study of a small cohort of wealthy families offers us a dazzling group portrait of an affluent elite moving through the Chancery proceedings, contributing in their progress to the stream of consciousness of polite society. Delicacy of manners, fit and proper feelings, shameful afflictions and moral compassion all figured in the legal exchanges and advertised the circumstances under which eminent psychiatrists gained their reputation and clientele among the fashionable and the well provided. It could be argued that the details of aristocratic household arrangements, public scandal and political conflict revealed by Lunacy Commissioners sketched a Hogarthian pageant far removed from the 'golden age' of the family invoked by bourgeois moralists. We see intense political and moral as well as personal confrontations over family fortunes, reflecting in part at least a larger social and cultural struggle in contemporary society which included bitter condemnation of moral standards among the 'best circles' of Britain. Suzuki shows that the professional survival of the medical celebrities who testified to the Lunacy Commission often depended on political acumen and moral credibility as much as scientific plausibility.

In restoring the importance of affluent households to the history of psychiatry, Suzuki draws on an impressive range of scholarship, including earlier work by Finnane (1981), Porter (1987b) and Tomes (1984) and recent research by Andrews (1999), Andrews and Digby (2004), Bartlett and Wright (1999), Marland (2004), Porter and Wright (2003) and others. Sharing their concern to uncover the significance of family ties in the 'lay' discovery and treatment of mental disorders, Suzuki distances himself from the pioneering research on American asylums by Nancy Tomes (1984) and her arguments regarding the emotional importance of kinship and the influence of families in the institutional treatment of the deranged. ${ }^{1}$ For Suzuki it was the material nexus of property rather than the tissue of sentiment which bound the family together and gave such a potent force to the affliction of insanity. In this respect at least, Madness at Home traverses 
much of the intellectual terrain occupied by earlier social history, including Marxist accounts of labouring households and insanity among poorer groups in industrializing societies.

For more than a generation historians have debated the importance of calculation, sentiment and affection in the responses by families and kinship communities to insanity during periods of intense economic and social change. ${ }^{2}$ There has been broad agreement that relatives and friends played an important part in the initial 'lay' identification of insanity, though historians have vigorously disputed the imperatives and motives of family behaviour in the use of their treatment of members and particularly in their resort to the lunatic asylum. Scull (1993) suggested that family bonds were weakened as labouring families sought to maximize their household income by depositing unproductive, dependent and disruptive members in the new institutions. Walton (1979) addressed the claims both of Scull and of Michael Anderson (1971) on the calculations made by labouring households struggling to cope with multiple demands on its human and material resources. Walton's subtle argument that tighter kinship groups and industrial communities with stable resources were more adept at using the asylum to cope with limited and short-term periods of difficulty have been widely noted. The capacity of families to control their world by managing their members and exploiting their opportunities by marriage and migration has remained an important theme in recent attempts to construct a cross-national model of insanity. ${ }^{3}$ The ways in which labouring families calculated and deployed their human resources, including the differential use of male and female children, indicates a distinctive and dynamic pattern of decision-making in the households of manual workers (Horrell and Humphries, 1995).

The recent 'revisionist' scholarship on the history of insanity and psychiatry, including Suzuki's impressive research, also presents us with challenging problems of interpretation. These arise partly from the conceptual and methodological difficulties of linking the micro-analysis of small cohorts, such as the 200 assembled in the present text, to broader models of demographic change and institutional provision. Linking the micro-foundations of human agency and collective choice to both social and political transformation has led Marxisant historians and family-oriented scholars since Porter in different directions. Claims about the impact of commercial market relations, industrial change and migration on family households need to be treated with considerable caution in discussing patterns of asylum admission and discharge. The absence of marital partners, a peripheral position in the kinship household and a lower propensity to migration were features likely to be associated with public asylum admission in the Victorian age. ${ }^{4}$ Labourers and domestic servants appeared more often than machinery workers, hawkers, prostitutes or the myriad social and occupational classes which populated town and country. Most certified lunatics came from nuclear family households but were usually under-represented in proportion to the 
other forms of domestic arrangements which sent members to these institutions (Melling and Forsythe, 2006). The complex patterns of aristocratic and affluent behaviour exposed among Suzuki's cases conflicted not only with bourgeois ideals of the harmonious nuclear household but even more so with the domestic arrangements of the labouring poor. It was the working population, including the mass of labouring, handicraft and petty commercial trades, who provided the bulk of asylum admissions in these and later decades.

Families with modest means were much less likely than the wealthy ones discussed by Suzuki to consult a psychiatrist about residential care or negotiate terms for institutional admission. They were even less likely to consider such medical practitioners to be paid servants and subject to their wishes, if not their direction, in the manner depicted by Madness at Home. These profound and continuing differences in familial experience of insanity during the nineteenth century illuminates the importance of social class in determining the provisions made for the Victorian lunatic in Britain and other countries. Suzuki's research indicates the degree to which the affluent family mediated relations of class as well as social rank and gender. Such concerns for social distinction and reputation helps to explain the growth of a segmented market or 'mixed economy' of institutional care for the insane, including the large number of private dwellings which served the needs of individual or small numbers of residential guests who appear in the British census return as lunatics, imbeciles and idiots. While evangelists such as Lord Ashley, whose own family was affected by insanity, remained hostile to the commercial exploitation of care for the insane, they were compelled to recognize that the middling classes were unlikely, if not ineligible, to use public asylums in the Victorian era. In paying fees for institutional or private care of family members, relatives were able to influence the terms of admission, treatment and discharge in ways which caused alarm during the panics over wrongful confinement in the 1880 s and paved the way for the 1890 Lunacy Act. The mixed economy of institutional care in these years was mirrored by a moral economy of household provision which ranged from compassionate and considered restraint to the indulgent and the abusive mistreatment of family misfits.

\section{Victorian frictions and psychiatric narratives}

Such variations in the legal processing and treatment of individuals have been obscured in part by the historical attention given to the employment of younger, frequently charismatic, psychiatrists as superintendents of the new asylums and the 'moral treatment' of their patients from the 1840s. The evidence offered in Madness at Home suggests that more compassionate forms of patient management grew out of the practical experience of domestic care offered by the families and emulated by the physicians of wealthier clients. 
This represents a clear refutation of Foucault's discussion of enlightenment reasoning and moral treatment as an exercise in bourgeois government of psyche and the human soul (Foucault, 2001). ${ }^{5}$ Suzuki elaborates his interpretation of Victorian psychiatry in references to J. C. Bucknill's celebrated text, written with D. H. Tuke, on the treatment of insanity (Bucknill and Tuke, 1858). A reading of Bucknill's psychiatric writings as well as his practical experience as superintendent of the Devon Asylum suggest that his thinking was more complex and less consistent than an endorsement of moral treatment or domestic harmony. Bucknill drew upon and displayed in his writings at least three different genres: firstly, a concern with the physical and biological characteristics of the brain and how these were expressed in the faces and bodies of the insane; secondly, a critical interest in cultural and poetic representations of madness (including Shakespeare's), as contrasted with the dismal and banal circumstances of most patients examined; and thirdly, an advocacy of the professional mission of psychiatry and the asylum in the face of widespread suspicion and even hostility among local communities and the wider public. Before his appointment to the Lord Chancellor's office as a Visitor in Lunacy, Bucknill registered his frustration not merely with the bumptious incompetence of poorly qualified medical men and the Poor Law authorities who often employed them; he also criticized the loose understanding of 'moral treatment' and the enormous practical problems of individual care in asylums deluged by hopeless, incurable cases dispatched from the workhouse wards of the county (Melling and Forsythe, 2006).

Bucknill's professional life illustrates the enormous social distance which separated, on the one hand, the wealthy client in a well-staffed household who was examined by an eminent physician, and, on the other, the distressed labourer found wandering at large or brought by parish overseers to the attention of the Relieving Officer at the workhouse. Suzuki is well aware of the need to contextualize his domestic model within the larger social world of Victorian England. He revives and reinvigorates the older historiography on the crowd in popular politics to show how the eccentric behaviour of the well-born or the wealthy could draw an assembly of the curious, alarming shamed relatives into action to secure legal and medical instruments to restrain the scandalous individual. Crowds might gather not merely to gape but also protest against the wrongful confinement, where a plausible narrative of dastardly action was dispersed among the throng of public witnesses. In recovering the public space in which lunacy was apprehended and subjected to the gaze of strangers, it is important to place the dramatic reflexes of transient or structured gatherings within the nexus of social rank and political geography which marked out the meaning of 'community' as well as the boundaries of kinship influence. The incidence or rumour of insanity could mobilize neighbours, petty officials, clergymen, teachers, evangelicals, policemen, game-keepers and other figures willing to offer 'facts of insanity' to doctors, magistrates and others dependent on their access to the scene. 
Suzuki draws a stark contrast between the privacy of the family home and the raucous realm of the street crowd, though the poorer lunatic was more readily the target of whispered suspicion, neighbourly gossip and the spread of tacit knowledge across a social space, as the skills of family and friends were stretched to cope and contain. The boundaries between public and private life in the thousands of villages and towns where the insane were identified were more porous than in fashionable London, where people frequently 'went mad' beyond the reach, resources or even knowledge of their immediate blood relatives or family of settlement. Similarly, the potent threat of violence or indecency, more particularly against the young and old, breached the fences of tacit control and tolerance shored up in communities when domestic dilemmas were exposed to public comment.

The abundant evidence presented in Madness at Home illustrates the various ways in which the family was itself reshaped by the economic, intellectual and cultural imperatives of the late eighteenth and early nineteenth centuries. While psychiatrists and others sought to appropriate and utilize the strengthening bourgeois ideal of domestic harmony, the vast array of labouring and petty-commodity households followed pathways that were different and distinctive from those found in the pages of this book. Suzuki seeks to locate the micro-politics of wealthy families within the web of capitalist globalization and the societal change transforming Britain in these decades, although the forces which were redefining the role and resources of families are only remotely perceived through the windows of the luxurious drawing room, the panelled chambers of the High Court, and the pages of The Times. Shifting our perspective to the changing landscape of British society enables us to encompass those circumstances where families were more often dependent upon, and responding to, upheavals in their environment rather than initiating strategies or inspiring institutional reform. In this light, we can see modernizing states as well as civil societies engaged in the progressive, even competitive, adoption of enlightened principles as a means of managing shifting populations and re-establishing the boundaries of tolerable behaviour through the employment of psychiatric imagination as well as fixed institutions. States as well as civil societies were pursuing social order viewed in terms of stable households, male supremacy, childhood education and civil responsibility which accorded well with the moral compassion espoused by evangelical religious reformers and the humane science of modern psychiatry.

\section{Notes}

1. For a critical response, see Dale and Melling, 2006.

2. Anderson (1971) and Stone (1977) were key contributions.

3. For example, Wright, Moran and Gouglas, 2003.

4. Long (2005) emphasizes the high quality of migrants from the countryside, for example. 
5. In this respect, Suzuki's findings contribute to the historical rehabilitation of the asylum and psychiatrists, suggested by the work of Porter among others.

\section{References}

Anderson, Michael (1971) Family Structure in Nineteenth Century Lancashire (London: Cambridge University Press).

Andrews, Jonathan (1999) Raising the tone of asylumdom. Maintaining and expelling pauper lunatics ar the Glasgow Royal Asylum in the nineteenth century. In J. Melling and B. Forsythe (eds), Insanity, Institutions and Society, 1800-1914: A Social History of Madness in Comparative Perspective (London: Routledge), 255-81.

Andrews, Jonathan and Digby, Anne (2004) Gender and class in the historiography of British and Irish psychiatry. In Sex and Seclusion, Class and Custody. Perspectives on Gender and Class in the History of British and Irish Psychiatry (Amsterdam: Rodopi), 7-44.

Bartlett, Peter and Wright, David (eds) (1999) Outside the Walls of the Asylum (London: Athlone), 1-24.

Bucknill, J. C. and Tuke, D. H. (1858) A Manual of Psychological Medicine, Containing the Lunacy Laws: The Nosology, Aetiology, Statistics, Description, Diagnosis, Pathology, and Treatment of Insanity, with an Appendix of Cases (London: J. \& A. Churchill).

Dale, Pamela and Melling, Joseph (2006) The politics of mental welfare. In Mental Illness and Learning Disability since 1850 (London: Routledge), 1-23.

Finnane, Mark (1981) Insanity and the Insane in Post-famine Ireland (London: Croom Helm).

Foucault, Michel (2001) Madness and Civilization: A History of Insanity in the Age of Reason (Abingdon: Routledge).

Horrell, Sara and Humphries, Jane (1995) Women's labour force participation and the transition to the male-breadwinner family, 1790-1865. Economic History Review, $48,25-64$.

Long, J. (2005) Rural-urban migration and socioeconomic mobility in Victorian Britain. Fournal of Economic History, 65 (1), 1-35.

Marland, Hilary (2004) Dangerous Motherhood: Insanity and Childbirth in Victorian England (Basingstoke: Palgrave Macmillan).

Melling, Joseph and Forsythe, Bill (2006) The Politics of Madness (London: Routledge).

Porter, Roy (1987a) A Social History of Madness: Stories of the Insane (London: Weidenfeld and Nicolson).

Porter, Roy (1987b) Mind-Forg'd Manacles: A History of Madness from the Restoration to the Regency (London: Athlone).

Porter, Roy and Wright, David (eds) (2003) The Confinement of the Insane. International Perspectives, 1800-1965 (New York: Cambridge University Press).

Scull, Andrew (1993) The Most Solitary of Afflictions: Madness and Society in Britain, 1700-1900 (New Haven, CT: Yale University Press).

Stone, Lawrence (1977) The Family, Sex and Marriage in England, 1500-1800 (London: Weidenfeld and Nicolson).

Tomes, Nancy (1984) A Generous Confidence: Thomas Story Kirkbride and the Art of AsylumKeeping, 1840-1883 (Cambridge: Cambridge University Press).

Walton, John (1979) Lunacy in the industrial revolution: a study of admissions in Lancashire, 1848-1850. Fournal of Social History, 13, 1-22.

Wright, David, Moran, James and Gouglas, Sean (2003) The confinement of the insane in Victorian Canada: The Hamilton and Toronto Asylums. In R. Porter and D. Wright (eds), The Confinement of the Insane. International Perspectives, 1800-1965 (New York: Cambridge University Press), 100-28. 